\title{
Distribution and conservation of Aniba Aubl. (Lauraceae Jussieu) species in Brazil
}

\author{
Carlos Henrique Franciscon ${ }^{1 *}$ \& Izildinha de Souza Miranda ${ }^{2}$ \\ ${ }^{1}$ Instituto Nacional de Pesquisas da Amazônia, Manaus, AM, Brasil \\ ${ }^{2}$ Universidade Federal Rural da Amazônia, Instituto Socioambiental e de Recursos Hidricos, Belém, PA, Brasil \\ *Corresponding author: Carlos Henrique Franciscon, e-mail: franciscon.carlos@inpa.gov.br
}

FRANCISCON, C. H., MIRANDA, I. S. Distribution and conservation of Aniba Aubl. (Lauraceae Jussieu) species in Brazil. Biota Neotropica. 18(3): e20170362. http://dx.doi.org/10.1590/1676-0611-BN-2017-0362

\begin{abstract}
This study conducts a biogeographical review of Aniba in Brazil, including its actual and potential distribution, and a review on the species conservation status. The potential distribution of each Aniba species was modeled using the Brazilian Plants and Fungi Biogeography system, which is interconnected with the SpeciesLink network. A consensus model based on up to five algorithms was used to model the potential distribution of each species. The endemism, conservation status and rarity of each species in Brazil were also analyzed. A total of 3059 records of 30 Brazilian Aniba species were found. In total, 16.1\% of the records were excluded because of the lack of valid names, and $53.4 \%$ were excluded because of the lack of georeference and name of the person who identified the record. The consensus model showed good results for species with 20 or more pixels. The other species had many errors, and their models could only be used to determine new areas for collections. Nine species were endemic to Brazil, and only three species showed no indicator of rarity. The geographical distribution of Brazilian Aniba species shows a predominantly Amazonian pattern. Only four species are not actually found in the Amazon. Some Amazonian species may also be found in Atlantic Forest areas, and many other species have the potential to live there. Our results indicate that only three species have no conservation problems, whereas 14 species have conservation problems, and 13 other species require further population studies to be best evaluated. Keywords: Amazonian, Atlantic Forest, Endemism, Models, Rarity.
\end{abstract}

\section{Distribuição e conservação das espécies de Aniba Aubl. (Lauraceae Jussieu) no Brasil}

Resumo: Este estudo objetiva apresentar uma revisão biogeográfica de Aniba no Brasil, incluindo a distribuição real e potencial, além de uma revisão sobre o estado de conservação das espécies. A distribuição potencial de cada espécie de Aniba foi modelada através do sistema Biogeografia da Flora e Fungos do Brasil (Biogeo), interligado à Rede SpeciesLink que integra em tempo real dados primários de coleções científicas com os quais foram estabelecidas a distribuição real das espécies. Um modelo de consenso, baseado em até cinco algoritmos, foi usado para modelar a distribuição potencial de cada espécie. Também foram analisadas a situação de endemismo no Brasil, o estado de conservação e raridade de cada espécie. Foram encontrados 3059 registros de 30 espécies de Aniba no Brasil. Em média houve uma perda 16,1\% dos registros por falta de nomes válidos e 53,4\% dos registros por falta de georreferenciamento e identificador. A avaliação do modelo consenso mostrou bons resultados para as espécies com 20 ou mais pixels, as demais espécies apresentaram muitos erros; sendo que seus modelos servem apenas para orientar novas áreas para coletas. Nove espécies são endêmicas do Brasil. Apenas três espécies não apresentaram nenhum indicador de raridade. A distribuição geográfica das espécies de Aniba no Brasil mostra um padrão predominante amazônico. Apenas quatro espécies não possuem ocorrência conhecida na Amazônia. Algumas espécies amazônicas também podem ser encontradas em áreas da Mata Atlântica e muitas outras apresentam potencial para ocorrer lá. Nossos resultados indicam que apenas três espécies não possuem nenhum problema referente à conservação, 14 espécies possuem problemas e 13 outras espécies necessitam de mais estudos populacionais para melhor serem avaliadas.

Palavras-chave: Amazônia, Mata Atlântica, Endemismo, Modelos, Raridade. 


\section{Introduction}

Aniba is the largest Lauraceae genus. It encompasses 92 registered species, with 96, 125 and 99 valid names in the Index Kewensis, The Plant List and TROPICOS, respectively. The Aniba species are concentrated in the South American region and are rarely found in Central America and the Antilles (Quinet 2005, Barbosa et al. 2012). Central Amazon and Guyana forests are considered dispersal centers of the genus (Kubitzki \& Renner 1982).

In general, Aniba species are commonly known as laurel, with many variations, mainly according to their odors, colors, exudates and similarities with other species: pichurim bean, oleander, cayenne rosewood, bois de sassafras, moena and itauba. The Tupi Indians referred to laurel plants in general as "ajuva", "aijuba" and "aniuba" (Pio-Corrêa 1926-1978).

Several Aniba species are exploited for the production of timber and essential oils used in perfume industries and traditional medicine. The oils contain flavonoids, riparins, pyrones, linalool, allylbenzene and benzoate (Maia \& Andrade 2009, Alcântara et al. 2010). Studies on the phytotherapeutic use of some species have proliferated in recent years, involving bioassays for some species, including A. riparia (Nees) Mez, A. canelilla (Kunth) Mez, A. rosiodora Ducke and A. hostmanniana (Nees) Mez (Simić et al. 2004, Lahlou et al. 2005, Nunes et al. 2014). However, the best-known species is A. rosiodora, commonly known as Brazilian rosewood; a linalool-rich essential oil is extracted from this species and has been used for decades as a fixative, including in the famous perfume Chanel No. 5 (Maia et al. 2007, Fonseca 2014).

Predatory exploitation and habitat destruction, particularly of species with restricted distributions, has prompted the inclusion of several species in the Red List of Threatened Species (IUCN, 2015) and/or in the Brazilian Flora Red List (BFRL 2015), including: $A$. ferrea Kubitzki, A. intermedia (Meisn.) Mez, A. pedicellata Kosterm., A. santalodora Ducke and $A$. rosiodora Ducke.

The morphological and taxonomic complexity of Lauraceae, particularly Aniba, places them in a group that is difficult to identify (Kubitzki \& Renner 1982, Quinet 2005, 2015). Consequently, identification errors in herbarium collections are very common. The use of common names of species, which do not always correspond to the scientific name, also hinders identification. Many forest, ethnobotanical, phytosociological or floristic inventories are key sources of information on species occurrence. However, fertile specimens are rarely collected, which would enable accurate identification, either for comparison in herbaria or by experts. Common names are usually given by a parataxonomist at the collection site, and these common names are used to search for the corresponding scientific name published in the literature, often referring to several species that are sometimes from very different taxonomic groups (Ferreira \& Hopkins 2004, Baraloto et al. 2007, Procópio \& Secco 2008). Species commonly known as laurel, with different variations (oleander, bois de sassafras, cayenne rosewood), may correspond to at least 50 species of the Lauraceae family and may belong to different genera, including Aniba, Ocotea and Mezilaurus (Quinet 2006, Ferraz et al. 2009). All of those problems lead to low numbers and a low quality of collection records in herbaria, which are considered the main problems for the analysis of spatial distribution of many plant species (Gaston \& García-Viñas 2010, Hassemer et al. 2016).

The establishment of multi-national information exchange between collections and the development of data networks has improved the accuracy, standardization and updating of identifications of specimens registered in herbaria (Canhos et al. 2015). For example, the SpeciesLink network (http://splink.cria.org.br) database integrates primary data on Brazilian species registered in 179 national and international herbaria. However, those databases still require experts to characterize the taxa, check synonyms, update the nomenclature and certify (or not) the person who identified the species, generating more accurate data that may support studies on species diversity and geographical distribution (Siqueira \& Durigan 2007).

Potential distribution models can be gerenated by correlating species occurrence points with environmental data (Soberón \& Peterson 2005). Such models may benefit from more accurate data becoming available through species occurrence data networks, and they may help guiding new fieldwork to obtain more records of a particular species (Bourg et al. 2005, Guisan et al. 2006, Siqueira et al. 2009). These models may also guide conservation actions, including the establishment of new priority conservation areas (Marco \& Siqueira 2009, Siqueira et al. 2009, Miller \& Morgan 2011), planning and conservation actions (Giannini et al. 2012, Addison et al. 2013) among other.

Recently, the Reference Center for Environmental Information (CRIA) and the Virtual Herbarium of Plants and Fungi (HVFF) of the National Institute of Science and Technology (INCT) created the Brazilian Plants and Fungi Biogeography system (Biogeo 2015 - http://biogeo.inct.florabrasil.net/) for expanding knowledge on the biogeography of plant and fungal species in Brazil. Biogeo provides an open-access tool to model potential distributions using up to five different algorithms, in addition to a consensus model.

Using that tool, this study aimed to conduct a biogeographical review of Aniba in Brazil, including the actual and potential distribution, in addition to a review on the species conservation status.

\section{Materials and Methods}

\section{Survey of species and synonyms}

The names and synonyms of Brazilian Aniba taxa were compiled based on the latest taxonomic review of the genus (Kubitzki \& Renner 1982), the List of Brazilian Plant Species (BFG, http://www. floradobrasil.jbrj.gov.br/) and the International Plant Names Index (http://www.ipni.org); the latter two are included in the main dictionaries and indexes of scientific names of angiosperms; both were consulted in December 2015.

\section{Species geographical distribution}

The actual distribution of each Aniba species was initially analyzed. For such purposes, all of the records of valid names existing in the SpeciesLink network database were considered. Those records were georeferenced either using the source collection or the dataCleaning (DC) app that was developed by CRIA (http://splink.cria.org.br/dc ). That app identifies possible spelling mistakes in species names and facilitates data standardization; the app does not change the information, and no data are modified. The app only identifies suspicious records and recommends that the author choose between correcting or not correcting the information. Subsequently, the selected data were analyzed using another tool that was also developed by CRIA, called geoLoc (http://splink.cria.org.br/geoloc), that aims to help with the 
biological collection work through georeferencing the collections by assigning municipality coordinates to records that lack longitude and latitude data in voucher labels.

In addition to all of the records (Rt) available at SpeciesLink, we also examined all of the labels and scanned images of the voucher specimens from virtual herbaria that were included or not in the collection data integration networks and publications in the fields related to our study, including plant ecology, forest and floristic inventories and, in particular, papers reporting the list of species and flowers from different locations. However, that material was only analyzed when the voucher specimen record was cited in an herbarium registered in the Index Herbariorum (http://sweetgum.nybg.org/science/ih/).

The potential distribution of each Aniba species was modeled using the Biogeo system, which is directly interconnected to the SpeciesLink, from where species occurrence records are retrieved. Biogeo uses openModeller software to generate potential distribution models (http:// openmodeller.cria.org.br/). Also developed by CRIA, openModeller openModeller is free, open-source, multi-algorithm software that supports multiple data formats; the software is specifically used to generate species potential distribution models based on environmental variables assigned to each training point or pixel (Muñoz et al. 2011).

Thus, the following three steps were required before generating species potential distribution models: (1) the application of filters to select the records to be included; (2) the search for environmental variables; (3) and the models productions. Lastly, the models were evaluated using a set of indicators.

\section{Record selection filters}

All of the data from the samples found, including valid synonyms, were individually revised based on all records (Rt) of each Aniba species found in SpeciesLink. Two records selection filters with the best data quality were applied as described in Giovanni et al. (2012). Only records with valid names (Rv) passed through the first filter (F1). Those records were then analyzed using Biogeo, wherein they passed through the second filter (F2), which only included records with different geographic coordinates and that had been identified by experts in the respective taxonomic group (Rgi). After the BioGeo system applied the filters all records were manually revised before being used to generate models.

Each record with a different coordinate was considered a training point inside a $\sim 1 \mathrm{~km}^{2}$ pixel. The records were aggregated into a single pixel to generate the models because many collections have the same coordinates or were performed very close to one another. Only the most recent records were considered in the case of duplicate records in the same collection or with conflicting identification between two or more collections. Samples lacking the name of the person who identified it or samples identified as derived from crops were not considered.

\section{Environmental variables}

Eight environmental variables were used, including one topographic variable (elevation) and seven bioclimatic variables from WorldClim (Hijmans et al. 2005) that have demonstrated no correlation in the Brazilian territory and that knowingly affect the distribution of great part of the vegetal species: (1) average daily temperature variation; (2) maximum temperature in the warmest month; (3) minimum temperature in the coldest month; (4) rainfall in the wettest quarter; (5) rainfall in the driest quarter; (6) rainfall in the warmest quarter; and (7) rainfall in the coldest quarter.

The elevation was directly obtained from the Global Climate Data WorldClim database (http://www.worldclim.org/current) to indirectly represent other factors, including incident solar radiation and atmospheric pressure, which usually strongly affect the distribution of plant species. The bioclimatic variables were also extracted from WorldClim (http://www.worldclim.org/bioclim) at an approximate spatial resolution of $1 \mathrm{~km}^{2}$. WorldClim provides data on bioclimatic variables derived from the monthly rainfall and temperature values, which may be selected and applied to any region of the planet and are commonly used in species distribution modeling (Giannini et al. 2012, Peterson \& Soberón 2012, Yanga et al. 2013).

\section{Potential distribution models production}

The potential distribution models produced are based on species presence data and on the environmental variables assigned to each pixel (Muñoz et al. 2011). In BioGeo, the number of pixels available determines which algorithm(s) may be processed and, depending on this number, up to five algorithms may be used, thereby generating up to five models, in addition to a consensus model (BioGeo 2015).

If there are less than five pixels, the environmental dissimilarity (ED) model was generated using the Euclidean distance in relation to the nearest point of occurrence, according to Carpenter et al. (1993). If there are five to nine pixels, maximum entropy (MaxEnt) was used, according to Phillips et al. (2006). The following three models were used if there are 10 to 19 pixels: 1) MaxEnt; 2) Genetic Algorithm for Ruleset Prediction - Best Subsets (GARP-BS), according to Anderson et al. (2003); and 3) a consensus model between the first two, as proposed by Biogeo. The following six models were used if there are 20 or more pixels: 1) MaxEnt; 2) GARP-BS; 3) Mahalanobis Distance (MD), according to Farber \& Kadmon (2003); 4) Ecological-Niche Factor Analysis (ENFA), according to Hirzel et al. (2002); 5) Support Vector Machines (SVM), according to Schölkopf et al. (2001); and 6) a consensus model between the five models above.

All of the models other than the ED model were transformed into binary models using a cutoff point based on the minimum training presence, also known as the lowest presence threshold. That method identifies and selects the lowest value of environmental suitability assigned by the model to a presence point of the set of pixels; that is, pixel values higher than the cutoff point are considered possible areas of presence (Phillips et al. 2006, Pearson et al. 2007).

The consensus model in BioGeo shows in each pixel the number of models predicting environmental suitability for the species. In the consensus model, the different levels of agreement between algorithms are described using different colors: red (for five algorithms), orange (four), yellow (three) and blue (less than three). Consensus has been helpful to support decision making on the distribution of various species (Chen 2009, Hassemer et al. 2016).

\section{Model evaluation}

Model quality evaluation also depends on the number of pixels used from Biogeo. Models with less than five pixels of occurrence are not tested; they only serve to indicate relatively close and environmentally similar areas where new botanical collections should be performed. 
Models with five to 19 pixels of occurrence were evaluated using the intrinsic omission rate and were tested using the leave-one-out procedure, subsequently calculating the probability associated with the number of successful predictions; that is, a new model is generated for each point using every other point and is subsequently tested using the point in question. After performing this process for all of the points, the probability of obtaining the number of successful predictions is calculated using a one-tailed Poisson-binomial test. In addition to the intrinsic and extrinsic omission rates, the area under the curve (AUC) was also analyzed in models with 20 or more pixels.

Omission is a type of error that occurs when the model fails to predict areas that are environmentally suitable for the species. The intrinsic omission rate was calculated using the same points used in model generation, whereas the extrinsic omission rate was calculated using points that were not used in model generation. The extrinsic omission rate was not calculated for the MaxEnt model. The intrinsic omission rate is usually suggested to not exceed $5 \%$, whereas the extrinsic omission rate should not exceed $20 \%$ (Peterson et al. 2008). The AUC is the relationship between the area from the model and the study area for each curve threshold; the values were calculated using 5-fold cross-validation, which is recommended for species with 20 to 199 pixels (Phillips et al. 2006). The AUC values were considered very good (AUC $>0.9)$, good $(>0.8)$ and reasonable $(>0.7)$, as advocated by Swets (1988).

\section{Endemism, conservation and rarity}

The species endemism in Brazil was analyzed by comparing the BFG (2015) classification with the national and international virtual herbarium data. The conservation status was evaluated based on the following three criteria: (1) presence on the IUCN Red List of Threatened Species (2015); (2) presence on the Brazilian Flora Red List (2015); and (3) presence in the classification of rarity by Rabinowitz et al. (1986).

The classification of rarity by Rabinowitz et al. (1986) suggests eight categories of rarity based on the simultaneous data of geographic range (wide or narrow), habitat specificity (broad or narrow) and local population size (abundant or sparse). The criteria by Serrato et al. (2004) were modified to categorize each Aniba species; the geographic range was defined by the number of pixels in which the species were found. Species with a narrow geographic range were found in less than 26 pixels, equivalent to a maximum of $25 \%$ of the number of pixels occupied by A. firmula (104 pixels, highest number of pixels among the Aniba species). The number of vegetation types in which the species were found was analyzed to determine the habitat specificity category; species with a narrow habitat only occurred in one type of vegetation. The data on habitats were gathered from Quinet et al. (2015) and herbarium voucher specimen labels. The local population size category was defined by the total number of records found in SpeciesLink (Tr); species with small populations had fewer than 172 records, which was equivalent to a maximum of $25 \%$ of the number of records of $A$. firmula (689 records, highest number of records among Aniba species).

The following are abbreviations of Brazilian states: Acre (AC), Alagoas (AL), Amapá (AP), Amazonas (AM), Bahia (BA), Ceará (CE), Distrito Federal (DF), Espirito Santo (ES), Goiás (GO), Maranhão (MA), Mato Grosso (MT), Mato Grosso do Sul (MS), Minas Gerais
(MG), Pará (PA), Paraíba (PB), Paraná (PR), Pernambuco (PE), Piauí (PI), Rio de Janeiro (RJ), Rio Grande do Sul (RS), Rio Grande no Norte (RN), Rondônia (RO), Roraima (RR), Santa Catarina (SC), São Paulo (SP), Sergipe (SE) and Tocantins (TO).

\section{Results}

\section{Names, synonyms and records of Aniba species in Brazil}

A total of 30 Aniba species were identified in the Brazilian territory; 48 valid synonyms were found for 19 of those species, and no synonyms were found for 11 species (Table 1).

In total, 3,538 Aniba records were found in Brazil, 479 of which were pre-excluded because they were only identified to the genus level. Thus, a total of 3059 records were analyzed using SpeciesLink, 345 of which were excluded because they had no valid names, leaving 2,714 records. Of these, 1,449 records were excluded because they were not georeferenced, and they lacked the name of the person who identified it. Finally, 1,265 records were considered that were grouped in 551 pixels (Table 2).

Considering the 30 species, the rate of loss was very high (56.4\%), with $11.3 \%$ lost in the first filter (valid names) and $53.4 \%$ lost in the second filter (georeferencing and name of the person who identified the record; Table 3). The mean loss of the 30 species was $16.1 \%$ in the first filter and $53.4 \%$ in the second filter, corresponding to a total loss of $64.1 \%$.

Six species had too few records and failed to pass through the filters (A. excelsa Kosterm, A. jenmanii Mez, A. kappleri Mez, A. muca (Ruiz \& Pav.) Mez, A. pedicellata and $A$. permolliis (Nees) Mez). A. kappleri, A. pedicellata and $A$. permolliis had too few records and were not georeferenced; $A$. excelsa, $A$. muca and $A$. jenmanii had very few records and were derived from the same samples. Some species $(A$. rosiodora and A. lancifolia Kubitzki \& W.A. Rodrigues) had very high loss rates in the first filter. $A$. rosiodora was the only species without losses in the second filter (Table 2).

\section{Model evaluation}

The MaxEnt model, which was applied to species with five to nine pixels (A.ferrea, A. lancifolia and A. santalodora), failed to show good results because the intrinsic omission rate values were well above $5 \%$ (Table 3), although the probability values were $<0.01$ (Poisson-binomial test). The same result was observed in most of the 12 species with 10 to 19 pixels. Only the species A. megaphylla Mez, A. riparia, A. terminalis Ducke and $A$. viridis Mez had models with good quality, and no differences occurred between the algorithms used among that group of species, except GARP-BS, which was more stringent in A. riparia.

The intrinsic omission rate of the eight species with more than 20 pixels was lower than $5 \%$ and therefore was acceptable. Among the six models applied to that group of species, the SVM and Mahalanobis models had AUC values lower than 0.9 and average extrinsic omission rate values higher than $20 \%$ for most species. The consensus model adequately described the results from the ENFA, GARP-BS and MaxEnt models. Only the species A. burchellii Kosterm., A. canelilla and A. williamsii O.C. Schmidt had higher extrinsic omission rates and lower AUC values, which are nonetheless classified as good (Table 3). 
Table 1. Names and synonyms of Brazilian Aniba species in SpeciesLink.

\section{Aniba affinis (Meisn.) Mez \\ $=$ Aydendron affine Meisn.}

2. Aniba burchellii Kosterm. No synomyms

3. Aniba canelilla (Kunth) Mez

= Aniba elliptica A.C. Sm.

= Cryptocarya canelilla Kunth

$=$ Cryptocarya pretiosa (Martiuse ex Ness)

= Laurus canelilla Willdenow*

= Mespilodaphne pretiosa (Martiuse ex Ness) Ness var. angustifolia Ness

4. Aniba citrifolia (Nees) Mez

= Aniba muelleriana $\mathrm{Mez}$

= Aniba trinitatis Mez

= Aydendron citrifolium Nees

= Cryptocarya pachycarpa Gleason

5. Aniba cylindriflora Kosterm. No synomyms

6. Aniba excelsa Kosterm.

No synomyms

7. Aniba desertorum (Nees) Mez No synomyms

8. Aniba ferrea Kubitzki No synomyms

9. Aniba firmula (Nees \& Mart.) Mez

= Aniba laevigata (Meisn.) Mez

= Aniba panurensis (Meisn.) Mez

= Aydendron firmulum Nees \& Mart.

$=$ Aydendron laevigatum Meisn.

= Aydendron panurense Meisn.

10. Aniba guianensis Aubl.

= Aniba salicifolia (Nees) Mez

= Aniba tessmannii O.C. Schmidt

= Aydendron salicifolium (Sw.) Nees

= Cedrota longifolia Willd.

11. Aniba heringeri Vattimo-Gil No synomyms

12. Aniba hostmanniana (Nees) Mez

= Aniba gigantifolia O.C. Schmidt

= Aniba pittieri O.C. Schmidt

=Aydendron hostmannianum Nees

13. Aniba intermedia (Meisn.) Mez

= Aniba puchury-minor var. intermedia (Meisn.) Kosterm.

= Aydendron intermedium Meisn.

14. Aniba jemannii Mez

= Aniba castanea C.K. Allen
15. Aniba kappleri Mez

= Aniba riparia (Nees) Mez

16. Aniba lancifolia Kubitzki \& W. A. Rodrigues

No synomyms

17. Aniba muca (Ruiz \& Pav.) Mez

= Aydendron muca (Ruiz \& Pav.) Nees

= Laurus muca Ruiz \& Pav.

= Ocotea oblanceolata Rusby

18. Aniba megaphylla Mez

= Aniba anisosepala Sandwith

= Aniba koumaroucapa Kosterm.

19. Aniba parviflora (Meisn.) Mez

= Aniba fragrans Ducke

= Aydendron parviflorum Meisn.

20. Aniba permollis (Nees) Mez

No synomyms

21. Aniba panurensis (Meisn.) Mez

= Aniba gonggrijpii Kosterm.

= Aniba mas Kosterm.

= Aydendron panurense Meisn.

22. Aniba pedicellata Kosterm.

No synomyms

23. Aniba puchury-minor (Mart.) Mez

= Aniba amazonica (Meisn.) Mez

= Aniba tessmannii O.C. Schmidt

= Aydendron amazonicum Meisn.

= Nectandra puchury-minor (Mart.) Nees

= Ocotea puchury-minor Mart.

24. Aniba riparia (Nees) Mez

$=$ Aydendron riparium Nees

25. Aniba rosiodora Ducke* In:

= Aniba duckei Kosterm.

= Aniba rosiodora var. amazonica Ducke

26. Aniba santalodora Ducke

No synomyms

27. Aniba taubertiana Mez

$=$ Aniba simulans C.K. Allen

28. Aniba terminalis Ducke

No synomyms

29. Aniba viridis $\mathrm{Mez}$

No synomyms

30. Aniba williamsii O. C. Schmidt

= Aniba gigantifolia O.C. Schmidt

= Aniba murcana C.K. Allen

= Aniba williamsii R.L. Brooks

(*) The specific epithet rosaeodora was corrected to rosiodora (ICN Art. 60.8 e Rec. 60G1 (Melbourne Code, 2011).

\section{Actual and potential distribution of Aniba species in Brazil}

Below, the actual occurrence of Aniba species is initially described based on Quinet et al. (2015) and Tropicos (http://www.tropicos.org/); thus, the results from the potential distribution found after applying the consensus model are shown. Data regarding habitats were gathered from Quinet et al. (2015) and from the herbarium voucher specimen labels. Environmental variables resulting from each species are shown in Appendix 1.
A. affinis (Meisn.) Mez.

Distribution: Model available at http://biogeo.inct.florabrasil.net/ proc/17806 (miniature map in Figure 1a). Amazon: AC, AM, RO, RR and MA. MG, wherein we found one record in the Rio Doce State Reserve (Reserva Estadual do Rio Doce), should also be included (E.P. Heringer 14000, NY). The consensus model indicates a higher probability for AM, AC, PA, AP, RR, MA, MT and TO; a lower probability for the Atlantic Forest from RJ to RN (area currently very destroyed and fragmented); and a significant - albeit unlikely - area in RS (Pampas) on the border with Uruguay. 
Franciscon, C.H. et al.

Table 2. Total number of records (Rt), records with valid names (Rv), georeferenced species records and the name of the person who identified it (Rgi), number of pixels (Px), percentage of loss in filter one (F1), percentage of loss in filter two (F2) and percentage of total loss found in databases used to build the models of Brazilian Aniba species distribution.

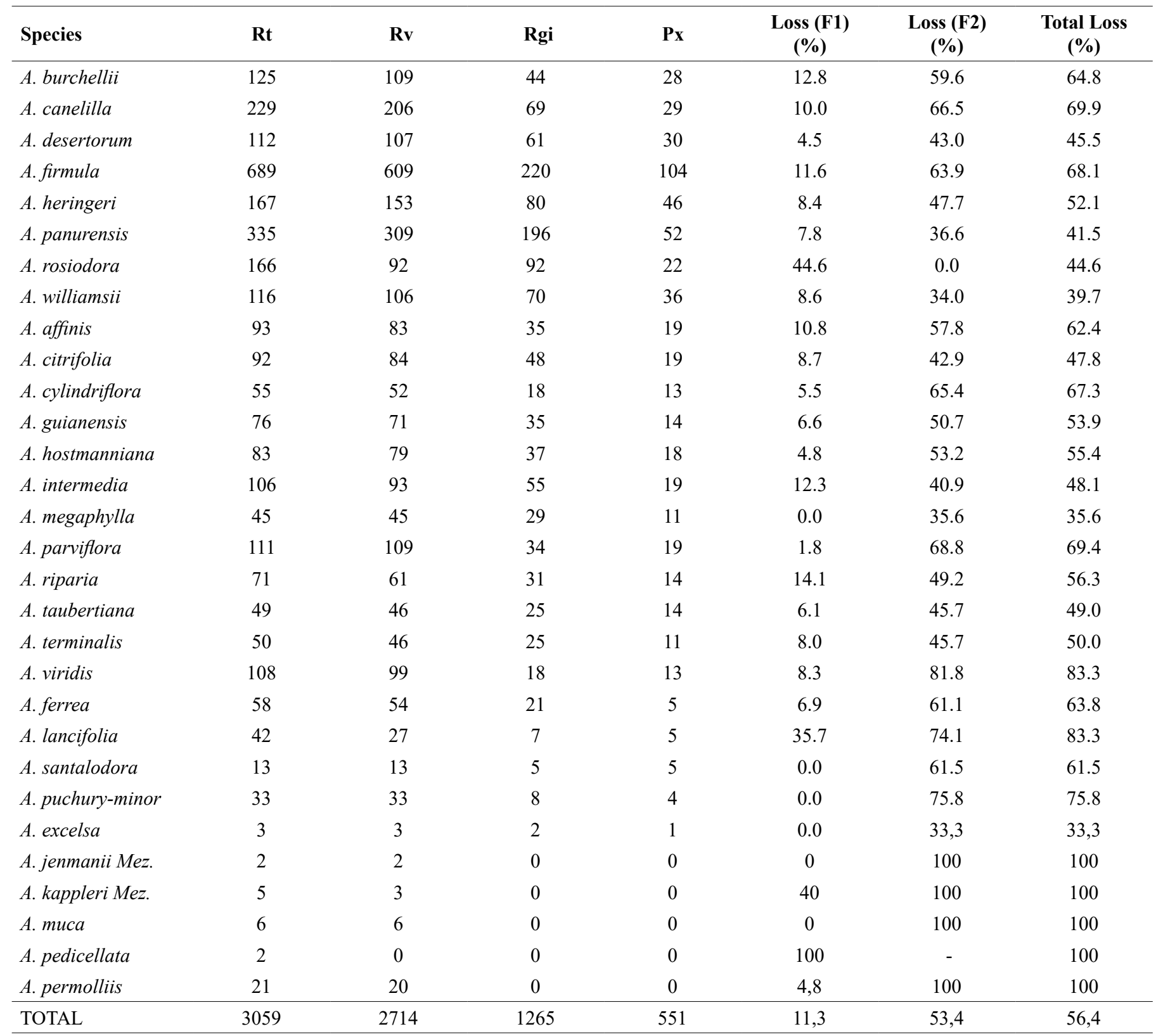

Habitat: Igapó forest (blackwater-flooded Amazonian forests), terra firme forest (flood-free Amazonian forest) and várzea forest (seasonally whitewater-flooded Amazonian forest), near the transition to terra firme. Sandy, clayey and clayey-sandy soils.

\section{A. burchellii Kosterm.}

Distribution: Model available at: http://biogeo.inct.florabrasil. net/proc/17794 (miniature map in Figure 2a). Amazon: AC, AM and PA. In the model, areas with high species occurrence probability are found in the Central Amazon, AC, AP, PA and RO. Low-probability and scattered areas are found in PE, AL, BA SP and PR and in the borders between GO, MS and MG.
Habitat: Campinarana (dryland forest on white-sand soil), várzea forest, rain forest, secondary forest in advanced stage of succession. Sandy soils.

\section{A. canelilla (Kunth) Mez}

Distribution: Model available at: http://biogeo.inct.florabrasil.net/ proc/16941 (miniature map in Figure 2b). Amazon: MT, AC, AM, AP, RO and RR, the Atlantic Forest and the Cerrado (Brazilian savanna; MS, ES and MG). The record found in MG is a sterile sample that lacks the name of the person who identified it; therefore, MG should be excluded from the actual distribution. The model indicates a high probability for the Amazon (AC, AM, AP, PA, RO and RR) and the Atlantic Forest 
Distribution and conservation of Aniba Aubl. (Lauraceae Jussieu) species in Brazil

Table 3. Quality indicators of the models applied to the Brazilian Aniba species: intrinsic omission rate (Oi), medium extrinsic omission rate (Om) and area under the curve (AUC). The probability value, derived from one-tailed Poisson-binomial test, is shown for species with less than 20 pixels.

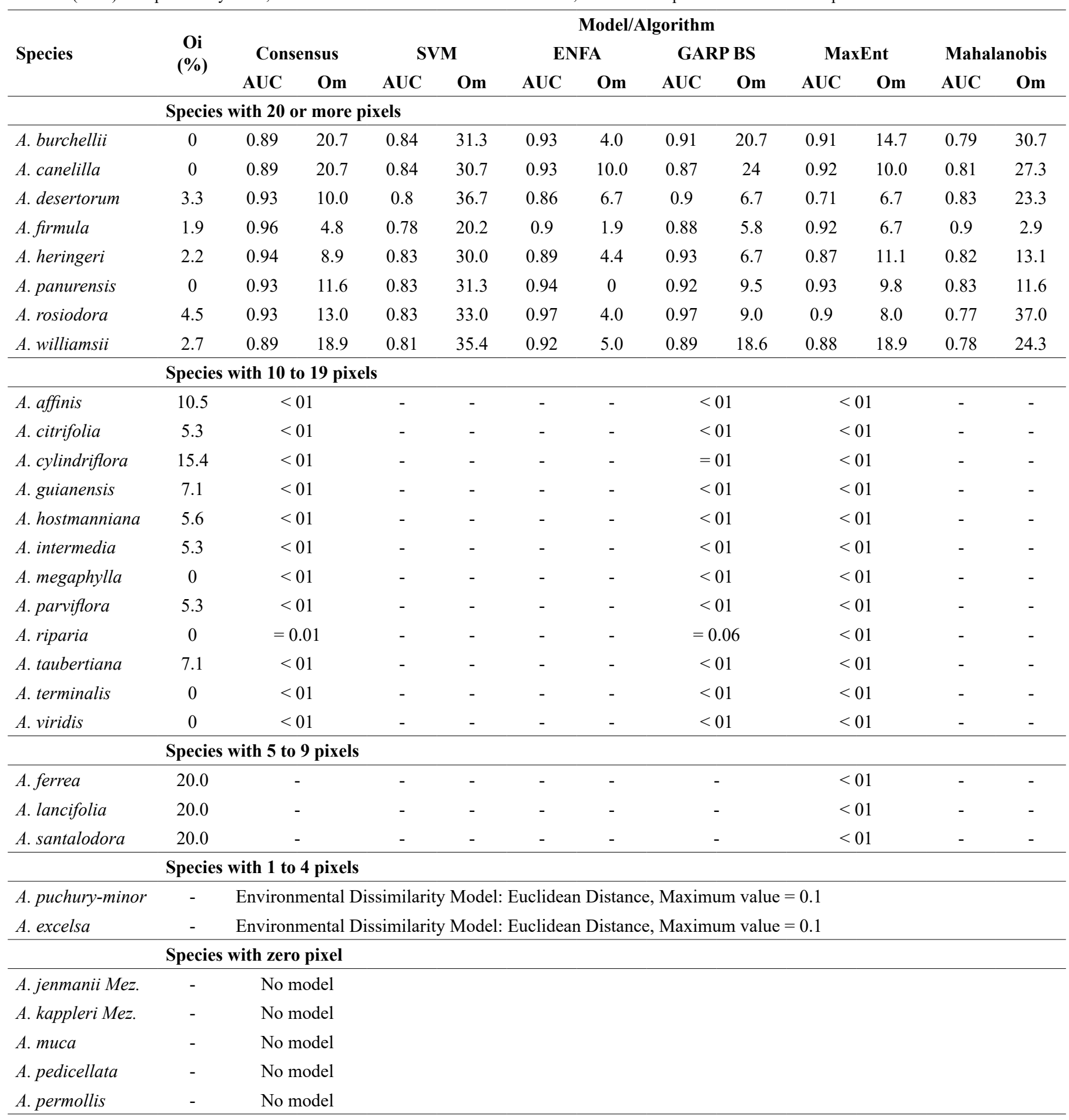

(MG and ES); patches in MA, RJ and MT; and an extended distribution to extra-Amazonian environments in the Pantanal and Cerrado of MS, GO, MG and SP. Occurrence is even less likely in northern PR and northeastern patches (TO, SE, AL, PE, RN, CE and PI).

Habitat: Terra firme forest, seasonal semi-deciduous forest, várzea forest and vegetation on rocky outcrops. Poorly drained, clayey and sandy-rocky soils.
A. citrifolia (Nees) Mez

Distribution: Model available at: http://biogeo.inct.florabrasil.net/ proc/17132 (miniature map in Figure 1b). Amazon: AM, AP, MA and PA. Our study detected actual occurrence in MT (R.L. Fróes, 1730, G). The consensus model extends the areas to MT, RR and TO (also in the Amazon) and CE and RN (in the Atlantic Forest). 


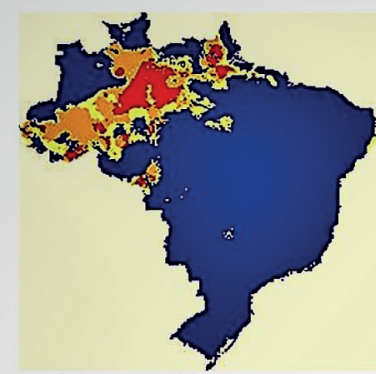

a) $A$. burchellii ( $\mathrm{n}=28$ pixels)

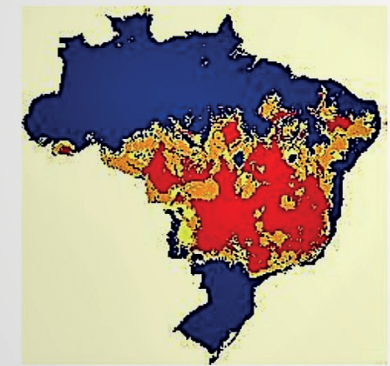

e) $A$. henrigeri $(\mathrm{n}=46$ pixels)

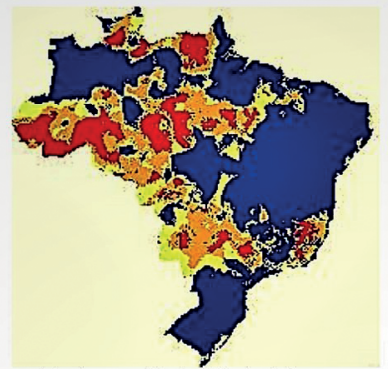

b) A. canelilla $(\mathrm{n}=29$ pixels $)$

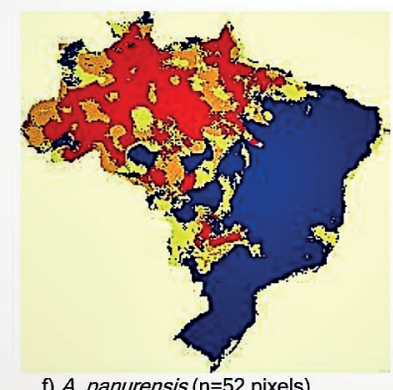

f) $A$. panurensis ( $n=52$ pixels)

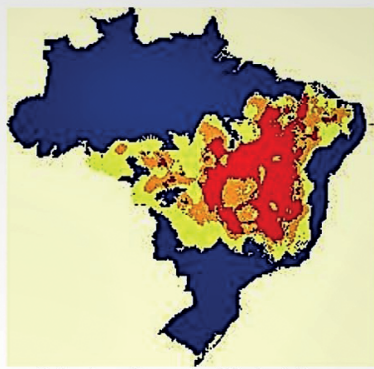

c) $A$. desertorum ( $\mathrm{n}=30$ pixels)

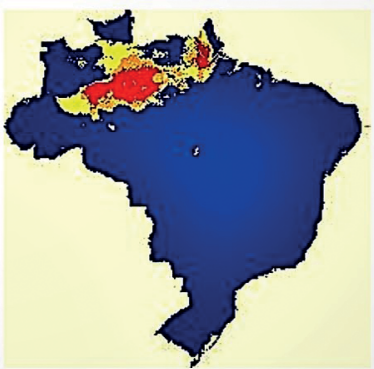

g) A. rosiodora ( $n=22$ pixels)

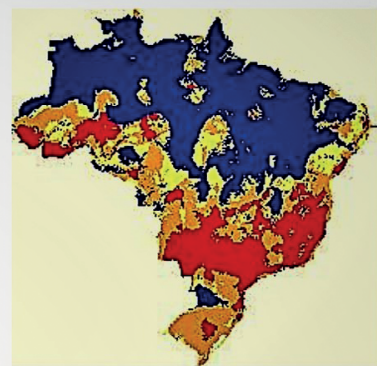

d) A. firmula ( $\mathrm{n}=104$ pixels)

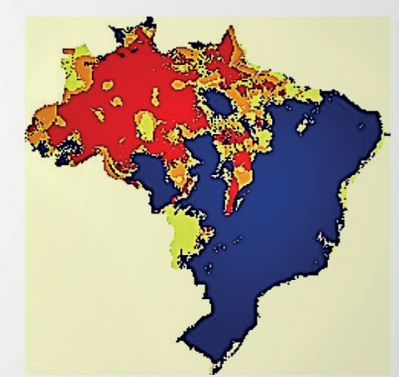

h) A. williamsii ( $\mathrm{n}=36$ pixels)

Figure 1. Potential distribution of Aniba species with 20 or more pixels. The colors represent areas of agreement between algorithms: red, 5 algorithms; orange, 4 algorithms; yellow, 3 algorithms, and blue, less than 3 algorithms.

Habitat: Terra firme forest, Várzea forest, transition vegetation between mangroves and sandy campina (shrubby vegetation with sparse trees), sandy savanna, secondary forest, Restinga (dunes) and mangroves. Sandy soils and terrain with granite rocks.

\section{A. cylindriflora Kosterm.}

Distribution: Model available at http://biogeo.inct.florabrasil. net/proc/17133 (miniature map in Figure 1c). Amazon: AM, AP, MT and RO. Our study detected actual occurrences in AC (L. Lima, 273, INPA) and RR (G.T. Prance, 4011, NY). The model extends the areas of potential species occurrence to the Amazon (AM, AP, MT and RO), Atlantic Forest (MA, RN, PB, PE, AL, SE and ES) and MS/TO (Bananal Island).

Habitat: Terra firme forest, Várzea forest, Igapó forest. Sandy and clayey-sandy soils.

\section{A. desertorum (Nees) Mez}

Distribution: Model available at http://biogeo.inct.florabrasil. net/proc/17134 (miniature map in Figure 2c). Caatinga (semi-arid vegetation) and Cerrado (savanna vegetation) including from grasslands to dense woodlands]): TO, BA, MA, PI, DF, GO and MG. The model expands the areas in the Cerrado and Caatinga, particularly in BA (which may be considered the distribution center of the species), DF and MT. $\mathrm{CE}, \mathrm{RN}, \mathrm{PB}$ and $\mathrm{PE}$ had low probability. There are no strong predictions for the Amazon, unlike the other Aniba species.

Habitat: Riparian forest, continental dunes, mesophytic forest. Sandy soils.

\section{A. excelsa Kosterm.}

Distribution: Model available at (http://biogeo.inct.florabrasil.net/ proc/17859), (miniature map in Figure 3a). Amazon: AM. The species has only three records (duplicates) from a collection in the Amazon, near São Paulo de Olivença, on the border of Colombia (D.C. Daly,
4410, INPA, NY). The model generated using exclusively ED indicates the surroundings of the collection area as the most appropriate area.

Habitat: Rain forest, undulating terrain, sandy soil.

\section{A. ferrea Kubitzki}

Distribution: Model available at: http://biogeo.inct.florabrasil. net/proc/17135 (miniature map in Figure 1d). Amazon: distribution restricted to AM and AP, as indicated by the MaxEnt model. With lower probabilities, new collections may be planned for the Solimões riverbed, between Manaus (AM) and Macapá (AP), and other more random sites may be examined in the coastal strip of the Atlantic Forest.

Habitat: Terra firme forest. Clayey, clayey-sandy and yellow latosol soil.

\section{A. firmula (Nees \& Mart.) Mez}

Distribution: Model available at: http://biogeo.inct.florabrasil. net/proc/17136 (miniature map in Figure 2d). Amazon, Cerrado and Atlantic Forest (BA, MT, ES, MG, RJ, SP; PR and SC). We found species occurrence records in AM (A.R. Oliveira, n.n. [without number], INPA), RO (N.M. Ivanauskas et al. 2182, ESA), PA (A. Ducke, n.n., INPA) and PE (D.S. Correia, 79; E.M.N. Ferraz, 853, PEUFR). The model indicates species occurrence almost throughout the AC in a long strip of Atlantic Forest (from RS to CE). Patches are present in SP, MG, ES, RJ, MT, GO, BA and MA and in a large area in the Pampas in the mountainous region of Santa Cruz do Sul (RS). A lower probability of species occurrence is indicated for TO, MS, RO, RR and MA.

Habitat: Seasonal semi-deciduous forest, rain forest, low secondary forest, hygrophilous forest, upper restinga (tropical and subtropical moist broadleaf) forest. Clayey soil.

A. guianensis Aubl.

Distribution: Model available at http://biogeo.inct.florabrasil.net/ proc/17137 (miniature map in Figure 1e). Amazon: AC, AM and AP. 


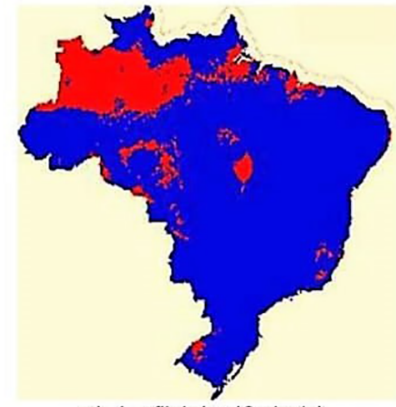

a) $A$. afiinis ( $n=19$ pixels)

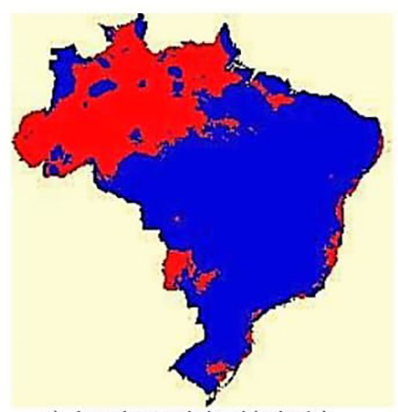

e) $A$. guianensis ( $n=14$ pixels)

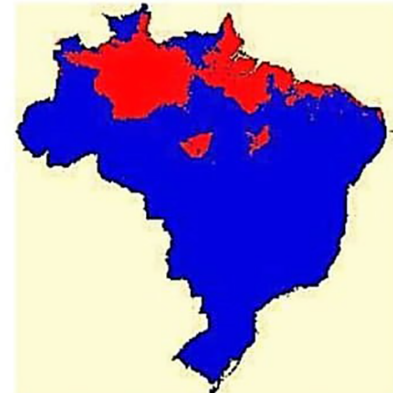

b) A. citrifolia ( $n=19$ pixels)

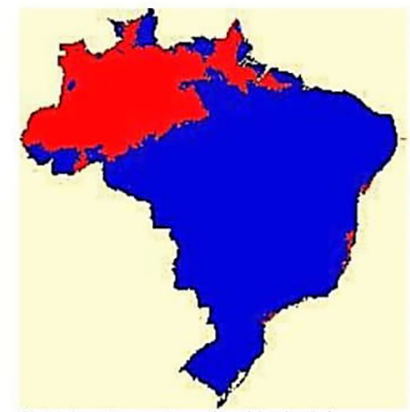

f) $A$. hostmanniana ( $n=18$ pixels)

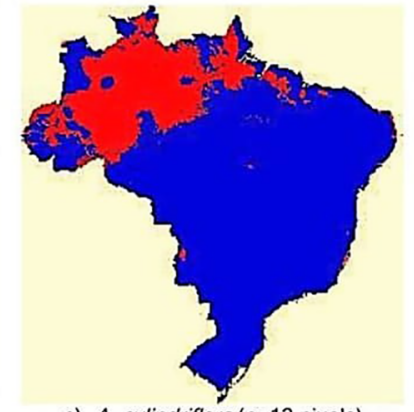

c) A. cylindriflora ( $\mathrm{n}=13$ pixels)

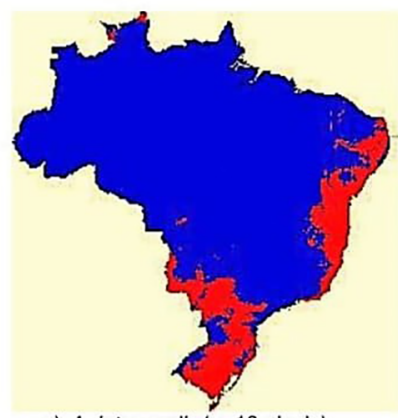

g) $A$. intermedia ( $\mathrm{n}=19$ pixels)

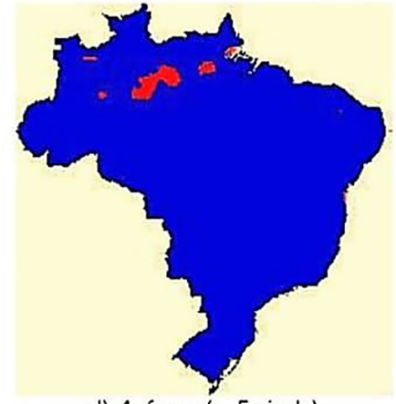

d) $A$. ferrea ( $n=5$ pixels)

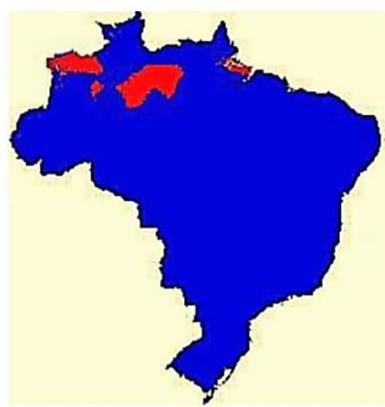

h) $A$. lancifolia ( $\mathrm{n}=5$ pixels)

(a)
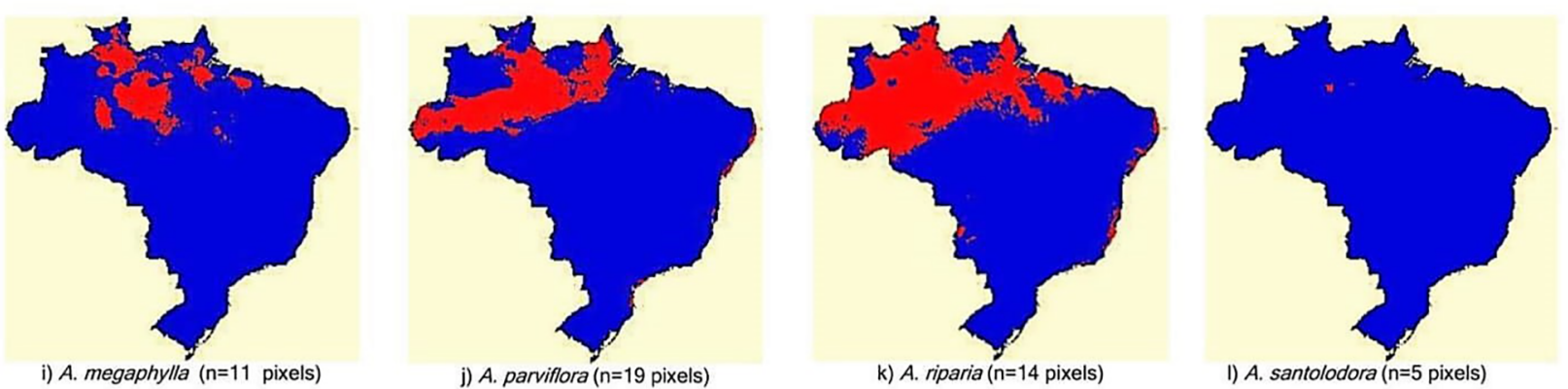

l) $A$. santolodora ( $\mathrm{n}=5$ pixels)

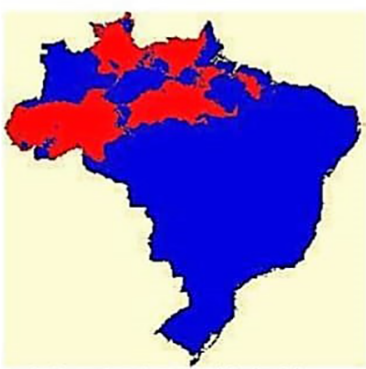

m) A. taubertiana ( $\mathrm{n}=14$ pixels $)$

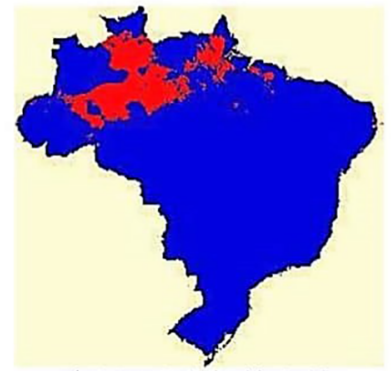

n) A. terminalis ( $\mathrm{n}=11$ pixels

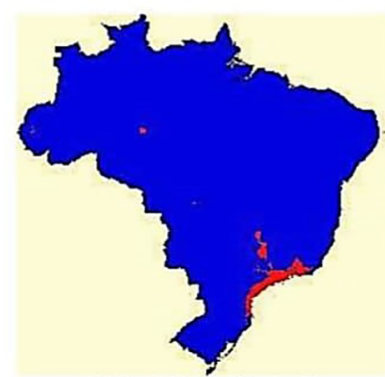

o) $A$. viridis ( $\mathrm{n}=13$ pixels)

(b)

Figure 2. Potential distribution of Aniba species with 5 to 19 pixels. The colors represent areas of agreement between algorithms: red, 2 algorithms, and blue less than 2 algorithms.

Our study extends the actual distribution to high Tapajós-PA (W.R. Anderson, 10800, MO), but no voucher specimen was found for Amapá (AP). However, the model indicates a large potential area in AP and almost all of AC; most of AM, RO, MS and ES; patches in RS, MA and PA; and small areas in the Atlantic Forest.
Habitat: Igapó forest, várzea forest, rain forest, secondary forest in a várzea area. Clayey, sandy, clayey-sandy and gleysol soil.

\section{A. heringeri Vattimo-Gil}

Distribution: Model available at: http://biogeo.inct.florabrasil. net/proc/17138 (miniature map in Figure 2e). Caatinga and Cerrado 

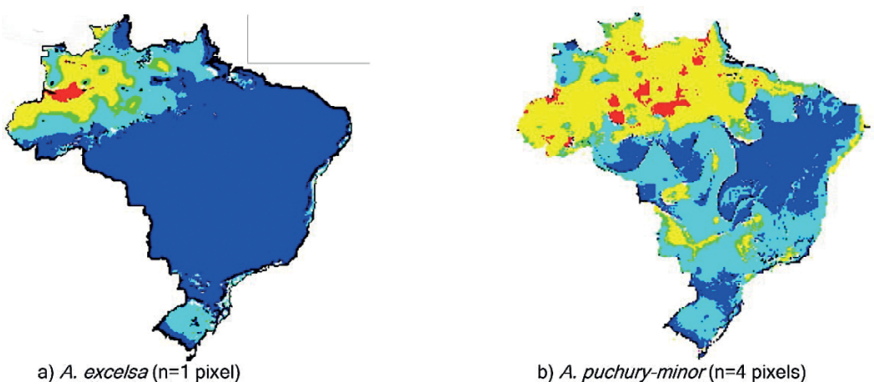

Figure 3. Potential distribution of Aniba species with 1 to 4 pixels.

(BA, TO, DF, GO, MS, MT, MG and SP). We detected actual species occurrence in MA (E.L. Taylor, 1271, HUEFS). The model indicates a high potential of species occurrence for much of MG, RJ, ES, PE, PB, CE, PI, AC, PA and RO. We may also find a lower probability of species occurrence in AM and AP.

Habitat: Riparian forest, seasonal semi-deciduous forest, Campos Rupestres (Montane savanna), várzea forest. Sandy-clayey soil with gravel.

\section{A. hostmanniana (Nees) Mez}

Distribution: Model available at: http://biogeo.inct.florabrasil.net/ proc/17139 (miniature map in Figure 1f). Amazon: AC, AM, PA and RR. We found voucher specimens for AP (H.S. Irwin, 47982, NY; W. Egler, $4673, \mathrm{~F})$. The model indicates a high potential of species occurrence in almost all of AM and much of RR and AP; it also expands into areas in PA and patches in the Atlantic Forest (PR, ES, BA and PE).

Habitat: Terra firme forest, várzea forest, secondary forest, forested campinarana, impacted Cerrado. Medium-texture, sandy, clayey and yellow latosol soil.

\section{A. intermedia (Meisn.) Mez}

Distribution: Model available at: http://biogeo.inct.florabrasil.net/ proc/17140 (miniature map in Figure 1g). Amazon (PA) and Atlantic Forest (AL, BA, CE, PB and MG). We only confirmed actual species occurrence in PA, BA and MG. No records were found in the other states. The consensus model indicates appropriate conditions in large areas of RS, SC, PR, MS, SP and southern BA and a strip in the coastal region, starting from RJ, covering much of ES, PB, SE and AL, almost all of $\mathrm{PE}$, patches in MT, AL, PB and RN and part of MG and ES.

Habitat: Seasonal semi-deciduous forest, rain forest, restinga, hygrophilous forest, riparian forest, vereda (palm swampy vegetation). Sandy-clayey and latosol soil.

\section{A. jenmanii $\mathrm{Mez}$}

Distribution: No model is available. We found two georeferenced records and the name of the person who identified this species, referring to duplicates from a collection in the Ducke Forest Reserve (Reserva Florestal Ducke), in Manaus-AM (J.Pruski, 3242, INPA and MO). These records were included in SpeciesLink early in 2016 and, have not yet been recognized by Biogeo. This precluded generating the model of this species.

Habitat: Rain forest.

\section{A. kappleri Mez}

Distribution: No model is available. The species is only mentioned for PA; however, three well-identified records were found, indicating species occurrence in PA near Marabá (R.P. Solomões, 318, CVRD), in AM near Manaus, in the Ducke Forest Reserve (M.S. Costa et al., 319, MBM) and in AP (H.S. Irwin, 48104, SP). Thus, its actual occurrence should be corrected to PA, AM and AP. Despite these three quite distant records, they lack coordinates for pixel generation.

Habitat: Rain forest.

\section{A. lancifolia Kubitzki \& W.A. Rodrigues}

Distribution: Model available at: http://biogeo.inct.florabrasil.net/ proc/13648 (miniature map in Figure 1h). Amazon: AM. Indeed, the species is underrepresented in Brazil, and the occurrence records are found in the campinas and campinaranas of the region near Manaus (AM). The MaxEnt algorithm extended the potential area of species occurrence with patches in the Upper Rio Negro in AM, in a narrow strip in southern AP and on Marajó island (PA). However, we believe that the Rio Negro basin is the most suitable location to collect the species because the species was only found in campinarana and campinas.

Habitat: Campinarana and campina.

\section{A. megaphylla Mez}

Distribution: Model available at: http://biogeo.inct.florabrasil.net/ proc/13649 (miniature map in Figure 1i). Amazon: AM, AP, PA and RR. We found one record in MT (C. Soares et al., 2015, HERBAM). The model indicates the potential for species occurrence in a wide strip between Itaituba (PA) and the Viruá National Park (Parque Nacional do Viruá, RR), involving areas in the Amazon (AM).

Habitat: Terra firme forest, secondary forest, forested campinarana. Sandy, clayey and sandy-rocky soil.

\section{A. тиса (Ruiz \& Pav.) Mez}

Distribution: No model is available. Amazon: AM and AP. Only two very old records of the 125 that are available in Tropicos (MOBOT) refer to Brazil; one refers to AM (B.A. Krukoff, 4724, MO, 1933) and the other refers to AP (Rosa, 1825, MO, 1977). However, those samples lacked the name of the person who identified them. We suggest a review of the Brazilian records to re-evaluate the occurrence of $A$. muca in Brazil because all other species records refer to Andean (Bolivian, Colombian, Ecuadorian, Peruvian and Venezuelan) forests.

Habitat: Terra firme forest, várzea forests.

A. panurensis (Meisn.) Mez

Distribution: Model available at: http://biogeo.inct.florabrasil. net/proc/17141 (miniature map in Figure 2f). Amazon: AC, AM, AP, PA, MA and MT. We found no voucher specimens for MA. Our study extends the occurrence to RO (G. Vieira et al., 305, MO; C.A. Cid, 7377, NY) and RR (G.T. Prance, 4011 NY). The model indicates a high potential of occurrence for the entire Amazon, including the Amazon areas of MA. A lower probability of species occurrence is indicated for MS, RJ and MG in the Triângulo Mineiro and in the border with ES; a patch is also indicated in southeastern SP and in a strip of Atlantic Forest from BA to CE. 
Habitat: Terra firme forest, secondary terra firme forest. Very clayey and yellow, sandy, clayey, clayey-sandy, and latosol soils.

\section{A. parviflora (Meisn.) Mez}

Distribution: Model available at: http://biogeo.inct.florabrasil. net/proc/17142 (miniature map in Figure 1j). Amazon: AC, AM, AP and PA. Our study indicated the occurrence of the species in MT at the Cristalino State Park (Parque Estadual do Cristalino; G.A. Gallo, 90, NY). The consensus model extended the areas of potential species occurrence towards the Upper Rio Negro, RR and AP and small strips of the Atlantic Forest from ES to PB. The consensus model indicated no area of potential species occurrence in MT, despite the record of actual species occurrence in this state. When the models were analyzed separately, only the MaxEnt model showed potential species occurrence in the region of MT. Therefore, in this case, we considered the MaxEnt model more appropriate than the consensus model.

Habitat: Terra firme forest, sandbank forest. Sandy, heavy-texture clayey, clayey-sandy, sandy-clayey, and clayey-silty soil.

\section{A. pedicellata Kosterm.}

Distribution: No model is available. Only two records were found, which were duplicates of a single individual collected in TeresópolisRJ in 1933 (Kulman s/n, RB), which was typified as a holotype (RB 19.958). Although it was considered valid, the records were recently removed from the BFG, SpeciesLink and Tropicos (MOBOT). The lack of any other record for over 80 years suggests that the species is extremely rare or, even worse, is extinct.

Habitat: Igapó forest, as mentioned in the original label.

A. permollis (Nees) Mez

Distribution: No model is available. Amazon: AM. Records qualified by name of the person who identified them indicate that the occurrence is restricted to AM in the region of Tefé and Manaus (Ducke Forest Reserve). However, those records failed to pass through the filters because they lacked georeferencing to generate pixels.

Habitat: Rain forest.

\section{A. puchury-minor (Mart.) Mez}

Distribution: Model available at: http://biogeo.inct.florabrasil.net/ proc/17097 (miniature map in Figure 3b). Amazon: AC and AM. The model generated using only ED indicates that the areas of AC, AM, $\mathrm{RR}, \mathrm{PA}, \mathrm{AP}$ and MA have high probabilities of finding populations. The Atlantic Forest and mesophilic forests of the interior of SP and MG represent less likely areas of potential occurrence.

Habitat: Terra firme forest, várzea forest.

\section{A. riparia (Nees) $\mathrm{Mez}$}

Distribution: Model available at: http://biogeo.inct.florabrasil.net/ proc/17098 (miniature map in Figure 1k). Amazon: AM, RO and RR. Our study extends the actual species occurrence to PA(D.C. Daly, 1194, NY; N.T. Silva, 45, MO). The consensus model extends the areas of potential occurrence to AC, AM, AP, MA, PA, RO and RR and small areas in MS and in the Atlantic Forest, with a lower probability of finding the species in ES, SE, AL, PB and RN.

Habitat: Terra firme forest, terra firme secondary forest.

\section{A. rosiodora Ducke}

Distribution: Model available at: http://biogeo.inct.florabrasil. net/proc/14748 (miniature map in Figure 2g). Amazon: occurrence restricted to AM, AP and PA. The consensus model extends the areas in these states and indicates the probability of occurrence in southern RR. This species has plantations in the Ducke Forest Reserve (AM) and in Curuá-Una (PA).

Habitat: Terra firme forest, in medium-texture sandy, heavy-texture clayey, sandy-clayey and yellow latosol soil.

\section{A. santalodora Ducke}

Distribution: Model available at: http://biogeo.inct.florabrasil.net/ proc/17143 (miniature map in Figure 11). Amazon: AM. Indeed, the species is restricted to a small area in the region of Manaus (AM). The MaxEnt model also merely suggests the area surrounding the Ducke Forest Reserve (Manaus - AM) for new botanical collections.

Habitat: Forested campinarana, terra firme forest, secondary forest at early stages of succession and the sandbank forests; sandy soils.

\section{A. taubertiana $\mathrm{Mez}$}

Distribution: Model available at: http://biogeo.inct.florabrasil. net/proc/17144 (miniature map in Figure 1m). Amazon: AM, PA, RO, RR and MT. However, we found no voucher specimen for MT in our study. The model extends the occurrence of the species to almost all parts of RR and AC, a large area in western AM that borders with AC and $\mathrm{RO}$, the northern part of $\mathrm{AP}$ and the border with $\mathrm{PA}$, a patch in MA and small strips in the Atlantic Forest.

Habitat: Terra firme forest, igapó forest, várzea forest, transition from field to forest. Clayey and rocky lateritic soil.

\section{A. terminalis Ducke}

Distribution: Model available at: http://biogeo.inct.florabrasil.net/ proc/13660 (miniature map in Figure 1n). Amazon: AM and PA. In this study, we extended the actual occurrence to AP (S.A. Mori, 16042, NY) and RO (G. Pereira-Silva, 16524, CEN). The consensus model expanded the probability of occurrence to the vicinity of Manaus, southern Roraima, part of AP, patches in the interior of PA and in the border with MA, in addition to strips in the Atlantic Forest.

Habitat: Terra firme forest, open rain forest. Clayey and yellow latosol soil.

\section{A. viridis $\mathrm{Mez}$}

Distribution: Model available at: http://biogeo.inct.florabrasil. net/proc/17145 (miniature map in Figure 1o). Atlantic Forest: RJ and SP. The consensus model expands the areas of these states and also indicates patches in AM (Juruena National Park (Parque Nacional do Juruena - PARNA de Juruena)), a strip from the interior of SP to MG (Triângulo Mineiro), a patch in MT and a coastal strip in SC and PR.

Habitat: Restinga, dense rain forest, secondary forest, restinga forest, seasonal semi-deciduous forest and mixed rain forest. Peaty soil.

\section{A. williamsii O.C. Schmidt}

Distribution: Model available at: http://biogeo.inct.florabrasil.net/ proc/17809 (miniature map in Figure 2h). Amazon: AC, AM, AP and PA. In this study, we detected the actual occurrence of the species in RO (G. 
Pereira-Silva, 16160, CEN). The consensus model indicates large areas of potential species occurrence in regions of $\mathrm{AM}, \mathrm{AP}$ and $\mathrm{RO}$ and parts of AC, PA and RR, with a lower probability in the borders between MT and TO (Bananal Island), TO and MA, and MT and GO. Areas of MS and the coastal strip of the Atlantic Forest had rather low probabilities.

Habitat: Terra firme forest, sandbank forest, forested campinarana, occasionally in campina, upper caatinga, impacted Cerrado, Amazon savanna. White-sandy, sandy-clayey, sandy-stony, yellow latosol soil.

\section{Endemism, conservation and rarity}

Most studied species (21) are not endemic to Brazil (Table 4). Four species (A. canellila, A. desertorum, A. ferrea and A. lancifolia) are mentioned as non-endemic to Brazil in the BFG (2015); however, no record of these species collected outside of Brazil was found. Eight other species ( $A$. burchellii, A. excelsa, A. henrigeri, A. intermedia,
A. parviflora, A. pedicellata, A. rosiodora and A. santalodora) are mentioned as endemic to Brazil in the BFG (2015); however, $A$. burchellii, A. parviflora and A. rosiodora records were found in other countries.

A. burchellii was found in Columbia (MO, S. Defler, 182, 183, 184); Peru (C.A. Grandez, 16178, MO) and Venezuela (A.H. Gentry \& B.A. Stein, 46809, 47086, MO). A. parviflora was found in Guyana (H.D. Clarke et al., 7533, 7722, MO), French Guyana (J.J. Grenville, et al., 14302, CAY, K, MO, NY, P), Peru (R. Vásques et al., 16828, 16833, MO) and Suriname (J. Donselaar, 1484, MO). A. rosiodora was found in French Guyana (M.F. Prévost \& P. Grenand, 4317, MO), Peru (A.H. Gentry et al., 26151; T.B. Croat, 18198, 18245,20749, MO) and Venezuela (G. Davidse \& J.S. Miller, 27187, MO).

Five species were found in the IUCN Red List of Threatened Species and in the BFRL (A. ferrea, A. intermedia, A. pedicellata, A. rosiodora

Table 4. Endemism, conservation status and categories of rarity based on classification of Rabinowitz et al. (1986) of Brazilian Aniba species. (NE) not evaluated; (DD) data deficient; (VU) vulnerable; (NT) near endangered; (EN) endangered; (CR) critically endangered.

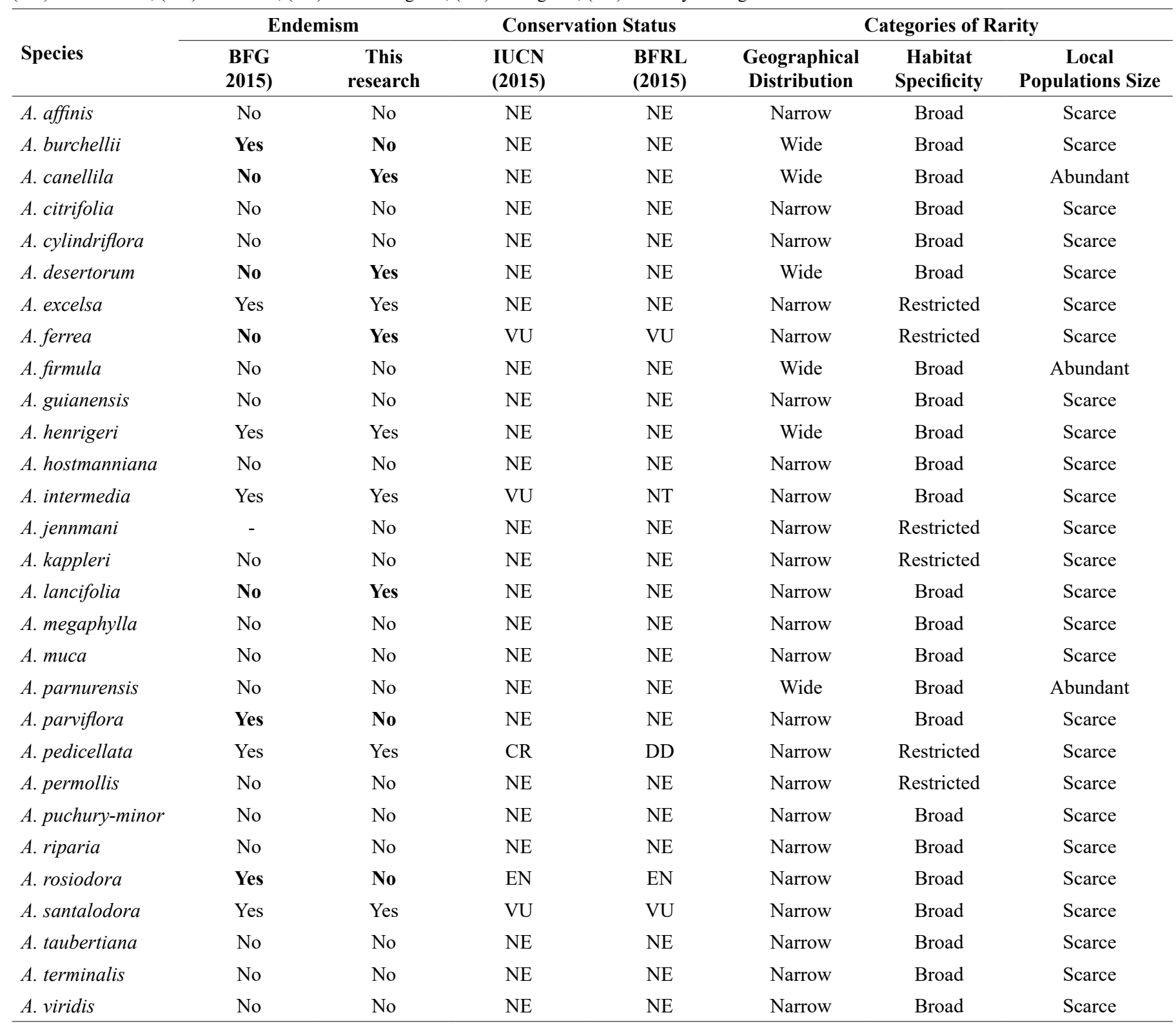


and A. santalodora), and one species (A. henrigeri) is not present on the IUCN Red List but can be found in the BFRL and São Paulo State Red List (Table 4).

The 30 Aniba species were classified into four categories of rarity according to Rabinowitz et al., (1986; Table 4): 1) common, with wide geographic distribution, broad habitat and abundant populations $(A$. canellila, A. firmula and A. panurensis); 2) intermediate rarity, with wide geographic distribution and broad habitat, albeit with sparse populations (A. burchellii, A. desertorum, A. henrigeri and A. williamsii); 3) alarming intermediate rarity, with narrow geographic distribution, broad habitat and sparse populations (group wherein most species are concentrated: A. affinis, A. citrifolia, A. cylindriflora, A guianensis, A. hostmanniana, A. intermedia, A. lancifolia, A. megaphylla, A. muca, A. parviflora, A. puchury-minor, A. riparia, A. rosiodora, A. santalodora, A. taubertiana, $A$. terminalis and $A$. viridis); and 4) highest-level rarity, with narrow geographic distribution, narrow habitat and sparse populations $(A$. excelsa, A. ferrea, A. jenmanii, A. kappleri, A. pedicellata and A. permollis).

\section{Discussion}

\section{Database and filters}

The BFG (2015) comprises 30 species of the genus. The record selection phase showed four different problems: 1) lack of synonyms in species databases; 2) invalid names in specimen labels, because the loss of data (11.3\%) may be considered high; 3 ) the lack of geographic coordinates in the voucher specimen records; and 4) the lack of the name of the person who identified the specimen. The first three problems are linked to the database and information recorded by herbaria, which must take action to correct those problems and perform a taxonomic review and update to better define the Aniba species. Notably, the BFG (2015) has only one synonym (Aydendron panurense for Aniba panurensis) and therefore was not the best source to select species and synonyms. The third problem is related to the collectors who must record the geographic coordinates, even if only approximate coordinates are available, namely those of the municipality where the species was collected. The fourth problem, which is much greater, is related to the lack of expert taxonomists for a reliable identification of samples. The lack of taxonomists in Brazil has already been highlighted by other authors (Ferreira \& Hopkins 2004, Hopkins 2007).

Six species (A. excelsa, A. jenmanii, A. kappleri, A. muca, A. pedicellata and $A$. permolliis) have few records, and none of those records passed through the filters applied. Plants may have few records in the collections for three reasons: 1) they have a narrow geographic distribution; 2) they have very sparse populations; and 3) they are seldom collected, which may lead to a false sense of species rarity, consequently resulting in erroneous assessments of the species conservation status (Siqueira et al. 2009) and limiting the identification of endemic areas because those areas may be confused with high-intensity collection areas (Murray-Smith et al. 2009).

In the Amazon, in particular, botanical collections are restricted to a few areas (Hopkins 2007, Schulman et al. 2007) and are sometimes confused with highly endemic areas (Nelson et al. 1990). However, even in areas with many botanical collections, including the region of Manaus-AM, only one individual each of $A$. jenmanii and A. kapleri were recorded, which suggests they are indeed rare; similarly, $A$. pedicellata only has one record from the municipality of Teresópolis (RJ), which is also a well-explored region. A different situation was observed for A. excelsa and A. muca, which have few records in poorly collected areas. This suggests the need for a greater collection effort. In turn, $A$. permolliis has 20 valid records, albeit none those were georeferenced or identified by an expert; that species could be prioritized by botanists to assess the identification and georeferencing.

\section{Models}

The number of records is directly related to the number of pixels used in Aniba models; the increase in the number of pixels or test points usually increases the accuracy (Stockwell \& Peterson 2002) and the number of successful predictions (Siqueira et al. 2009) of the models. Our results also showed that species with the lowest number of pixels had the highest values of intrinsic omission (5 pixels $-20 \%$ intrinsic omission) and the species with the highest numbers of pixels had the lowest values of intrinsic omission (more than 20 pixels); however, the intrinsic omission of species with six to 19 pixels varied widely (from zero to $20 \%$ ). In general, intrinsic omission seemed a good indicator to evaluate model performance across our experiments.

The GARP BS, MaxEnt and consensus models showed good performance when applied to species with five to 19 pixels. The MaxEnt model was only better than the consensus model for $A$. parviflora because the consensus model failed to identify the MT region as an area of potential occurrence of the species, although A. parviflora actually occurs in MT. Unlike the recommendation of Biogeo, which recommends the use of the above-mentioned models to predict areas of potential occurrence when $<20$ pixels are available, we agree with Pearson et al. (2007) who recommended those models as tools to identify regions with similar environmental conditions; the identification of those regions is important for conducting new field surveys, thereby accelerating the discovery of unknown populations. Notably, that recommendation is already accepted for species with less than five pixels.

For species with 20 or more pixels, the results of intrinsic omission, average extrinsic omission and AUC were in agreement and indicate good models. Intrinsic omission $<5 \%$ and an AUC close to 1.0 were emphasized as good indicators by Anderson et al. (2003) and Peterson et al. (2008). Despite the known limitations to test potential distribution models that are generated with presence-only data, since there are no absence data or actual potential distribution to be used as a reference (see Pearson 2007 and Peterson et al. 2008 for more detailed discussions), predicting species potential distribution remains an important task, even when model accuracy cannot be perfectly measured (Lobo 2008, Lobo et al. 2008, Rupprecht et al. 2011)."

\section{Aniba distribution in Brazil}

The geographic distribution of Aniba species in Brazil shows a predominance in the Amazon. Only four species (A. desertorum, A. henrigeri, A. pedicellata and $A$. viridis) do not occur in the Amazon; however, $A$. henrigeri has great potential of occurrence in this biome. Some Amazonian species may also be found in Atlantic Forest areas (A. canellila, A. firmula and A. intermedia), and many others only have the potential to occur in the Atlantic Forest (A. affinis, A. burchellii, $A$. citrifolia, A. cylindriflora, A. ferrea, A. guianensis, A. hostmanniana, $A$. 
panurensis, A. parviflora, A. puchury-minor, A. riparia, A. taubertiana, $A$. terminalis and $A$. williamsii). That potential of occurrence should be examined, particularly in some conservation units. Herein, we highlight the Rio Doce State Park, which has approximately 35,970 hectares of Atlantic Forest and crosses the municipalities of Marliéria, Dionísio and Timóteo in southwestern Minas Gerais. The natural vegetation extends beyond the boundaries of Minas Gerais, crossing part of the Linhares municipality in ES.

Some species of this study have been recorded in the Rio Doce State Park, and the model indicated suitable conditions for crop growth and conservation for other species. Furthermore, the park offers access to a research center to assist researchers, a nursery and an environmental police station, rendering it a key unit to implement and develop population conservation and recovery projects, particularly populations of threatened species or species regarded as rare.

However, the potential distribution in the Atlantic Forest is hampered by the reduction and fragmentation of that biome and associated ecosystems (Restinga salt marshes, mangroves and highlands), which originally encompassed approximately $1,300,00$ $\mathrm{km}^{2}$ in 17 Brazilian states. The native vegetation is currently reduced to approximately $22 \%$ of its original plant cover and is at different stages of regeneration. Only approximately $7 \%$ of the vegetation is well conserved in patches over 100 hectares in size (Ministério do Meio Ambiente do Brasil, http://www.mma.gov.br/biomas/mata-atlantica). Legal instruments determining strategies for the conservation and sustainable use of biodiversity in this biome, including promoting the recovery of degraded areas and the sustainable use of native vegetation (Law 11.428, of 2006 and Decree 6.660 of 2008), were only recently enacted. Similar to the Amazon, the Atlantic Forest has various endemic and threatened species and, even if reduced and fragmented, has environmental conditions suitable to house other threatened species, including some mentioned in this study.

The species $A$. canellila, $A$. desertorum, $A$. firmula and $A$. henrigeri occur in the Cerrado region of central Brazil, and A. burchellii and $A$. panurensis can potentially be found there. The species $A$. desertorum and $A$. henrigeri occur in the Caatinga region, and there is no high probability of occurrence of other species. Two Brazilian biomes have no records of Aniba, although a small potential of occurrence may be considered for Pantanal (A. canellila, A. cylindriflora and A. williamsii) and Pampas ( $A$. affinis and $A$. firmula), mainly because of the wide ecological amplitude of those species; their occurrence in Pantanal and Pampas would be unprecedented because there are no records of Aniba in these biomes thus far.

\section{Endemism, conservation and rarity}

Nine Aniba species are endemic to Brazil (A. canellila, A. desertorum, A. excelsa, A. ferrea, A. henrigeri, A. intermedia, A. lancifolia, A. pedicellata and $A$. santalodora), and our result indicates the need to review the BFG (2015). Those species have characteristics that raise some degree of concern, except for A. canellila, which is present in several Brazilian biomes. The species A. excelsa, A. Lancifolia and $A$. pedicellata are endemic to Brazil and are found in well-located areas. A. excelsa is endemic to the Rio Negro basin, A. lancifolia is endemic to campinarana and campina areas near Manaus, and $A$. pedicellata occurs exclusively in Rio de Janeiro (RJ). The species $A$. ferrea, A. intermedia, A. pedicellata and A. santalodora are already included in the IUCN Red List of Threatened Species. However, $A$. excelsa and $A$. lancifolia are not yet included, and our results indicate the need to include those species in the Red Lists.

The only species with many records and no degree of rarity were A. canellila, A. firmula and A. parnurensis; the other species displayed some degree of concern regarding their conservation status. In addition to the species cited above, we consider the situations of $A$. jenmanii, $A$. kappleri and A. permollis, which have few occurrences in Brazil and more specifically in the Amazon areas, very alarming. Therefore, those species must also be included in the Red Lists.

The following 14 species have a lower degree of rarity, albeit no less alarming: A. affinis, A. citrifolia, A. cylindriflora, A. guianensis, $A$. hostmanniana, A. megaphylla, A. muca, A. parviflora, A. puchury-minor, A. riparia, A. rosiodora, A. taubertiana, A. terminalis and $A$. viridis, and only one is classified as endangered by the IUCN (A. rosiodora). The others, which have not yet been evaluated by the IUCN, require further population studies to be better classified.

\section{Supplementary material}

The following online material is available for this article:

Appendix 1 - Environmental variables WorldClim recorded for the set of points of occurrence to 26 species of Aniba: $(\mathrm{Pu}+)$ rainfall in the wettest quarter; $(\mathrm{Ps}+)$ rainfall in the driest quarter; $(\mathrm{Pq}+)$ rainfall in the warmest quarter; $(\mathrm{Pf}+)$ rainfall in the coldest quarter; $(\mathrm{Vt} / \mathrm{d})$ average daily temperature variation; $(\mathrm{Tq}+)$ maximum temperature in the warmest month; (Tf -) minimum temperature in the coldest month; Elevation (topographic indirect variable).

\section{Acknowledgements}

This study was funded by the Fundação de Amparo à Pesquisa do Estado do Amazonas (FAPEAM). Carlos Henrique Franciscon was supported by a FAPEAM Doctoral Fellowship. The authors thank Renato De Giovanni, Centro de Referência em Informação Ambiental (CRIA), and Ely Simone Rangel, Pedro Viana and Antônio Elielson Rocha for their valuable comments aimed at improving the quality of this paper.

\section{Author Contributions}

Carlos Henrique Franciscon: substantial contribution in the concept and design of the study; contribution to data collection and interpretation; and, contribution to manuscript preparation.

Izildinha S. Miranda: contribution to data analysis and interpretation; contribution to critical revision, adding intelectual content.

\section{Conflicts of Interest}

The authors declare that they have no conflict of interest related to the publication of this manuscript. 


\section{References}

ADDISON, P.F.E., RUMPFF, L., BAU, S.S., CAREY, J.M., CHEE, Y.E., JARRAD, F.C., MCBRIDE, M.F. \& BURGMAN, M.A. 2013. Practical solutions for making models indispensable in conservation decision-making. Diversity and Distribution. 19: 490-502.

ALCÂNTARA, J.M., YAMAGUCHI, K.K., VEIGA-JUNIOR, V.F.D. \& LIMA, E.S. 2010. Essential oils composition from Aniba and Licaria species and their antioxidant and antiplatelet activities. Química Nova. 33: 141-145.

ANDERSON, R.P., LEW, D. \& PETERSON, A.T. 2003. Evaluating predictive models of species' distributions: criteria for selecting optimal models. Ecological Modelling. 162: 211-232.

BARALOTO, C., FERREIRA, E., ROCKWELL, C. \& WALTHIER, F. 2007. Limitations and applications of parataxonomy for community forest management in southwestern Amazonia. Ethnobothany Researches Applied. 5: 77-84.

BARBOSA, T.D.M., BAITELLO, J.B., \& MORAES, P.D. 2012. A família Lauraceae Juss. Município de Santa Teresa, Espírito Santo. Boletim do Museu de Biologia Mello Leitão. 30: 5-178.

BFG, Brazilian Flora Group. 2015. Lista das Espécies da Flora do Brasil. Jardim Botânico do Rio de Janeiro, Rio de Janeiro. Available from: http:// floradobrasil.jbrj.gov.br/(accessed: December 2015).

BFRL, Brazilian Flora Red List. 2012. Lista Vermelha da Flora do Brasil. Available from: http:/cncflora.jbrj.gov.br, (accessed: March 2016).

BIOGEO Biogeografia da Flora e Fungos do Brasil. 2015. http://biogeo.inct. florabrasil.net/ (last access in Dec 18, 2015).

BOURG, N.A., MCSHEA, W.J. \& GILL, D.E. 2005. Putting a cart before the search: Successful habitat prediction for a rare forest herb. Ecology. 86: 2793-2804.

CANHOS, D.A.L., SOUSA-BAENA, M.S., SOUZA, S., MAIA, L.C., STEHMANN, J.R., CANHOS, V.P., GIOVANNI, R., BONACELLI, W.L. \& PETERSON, A.T. 2015). The Importance of Biodiversity infrastructures for Megadiverse Countries. PLoS Biol. 13(7) e 1002204.

CARPENTER, G., GILLISON, A.N. \& WINTER, J. 1993. DOMAIN: A flexible modeling procedure for mapping potential distributions of animals and plants. Biodiversity and. Conservation. 2: 667-680.

CHEN, Y.H. (2009) Conservation biogeography of the snake family Colubridae of China. North-Western Journal of Zoology. 5: 251-262.

CRIA Centro de Referência em Informação Ambiental. 2015. speciesLink. http:// splink.cria.org.br/ (last access in May 14, 2016).

FARBER, O. \& KADMON, R. 2003. Assessment of alternative approaches for bioclimatic modeling with special emphasis on the Mahalanobis distance. Ecological Modelling. 160: 115-130.

FERRAZ, J., BARATA, L.E., SAMPAIO, P.D.T. \& GUIMARÃES, G.P. 2009. Perfumes da floresta Amazônica: em busca de uma alternativa sustentável. Ciência e Cultura 61: 40-43.

FERREIRA, G.C. \& HOPKINS, M.J.G. 2004. Manual de identificação botânica e anatômica-angelim. Embrapa Amazônia Ocidental, Belém. 112 p.

FONSECA, O.J.M. 2014. Acesso e uso da Biodiversidade. Hileia 7: 13-14.

GASTÓN, A. \& GARCÍA-VIÑAS, J.I. 2010. Updating coarse-scale species distribution models using small fine-scale samples. Ecological Modelling. 221: $2576-2581$

GIANNINI, T.C., SIQUEIRA, M.F., ACOSTA, A.L., BARRETO, F.C.C., SARAIVA, A.M. \& ALVES-DOS-SANTOS, I. 2012 Desafios atuais da modelagem preditiva de espécies. Rodriguésia 63: 733-749.

GIOVANNI, R., BERNACCI, L.C., SIQUEIRA, M.F., ROCHA, F.S. 2012. The Real Task of Selecting Records for Ecological Niche Modelling. Natureza \& Conservação, 10: 139-144.

GUISAN, A., BROENNIMANN, O., ENGLER, R., VUST, M., YOCCOZ, N.G., LEHMANN, A. \& ZIMMERMANN, N.E. 2006. Using niche-based models to improve the sampling of rare species. Conservation Biology 20: 501-511.

HASSEMER, G., GIOVANNI, R. \& TREVISAN, R. 2016. The use of potential distribution models in the study of the distribution and conservation status of plants: The case of Plantago L. (Plantaginaceae) in Brazil. Journal of the Torrey Botanical Society 143: 38-49.
HIJMANS, R.J., CAMERON, S.E., PARRA, J.L., JONES, P.G. \& JARVIS, A. 2005. Very high resolution interpolated climate surfaces for global land areas. International Journal of Climatology 25: 1965-1978.

HIRZEL, A.H., HAUSSER, J., CHESSEL, D. \& PERRIN, N. 2002. Ecologicalniche factor analysis: how to compute habitat-suitability maps without absence data? Ecology. 83: 2027-2036.

HOPKINS, M. J. 2007. Modelling the known and unknown plant biodiversity of the Amazon Basin. Journal of Biogeography. 34: 1400-1411.

IUCN 2015. The IUCN Red List of Threatened Species. Version 2015-4. Available from: http://www.iucnredlist.org> (accessed: 15 March 2016).

KUBITZKI, K. \& RENNER, S. 1982 Lauraceae I (Aniba and Aiouea). Flora Neotropica 31. New York Botanical Garden, New York. 125p.

LAHLOU, S.P., MAGALHÃES, P.J., SIQUEIRA, R.J., FIGUEIREDO, A.F., INTERAMINENSE, L.F., MAIA, J.G.S. \& SOUSA, P.J.C. 2005 Cardiovascular effects of the essential oil of Aniba canelilla bark in normotensive rats. Journal of Cardiovascular Pharmacology 46: 416-421.

LOBO, J., JIMÉNEZ-VALVERDE, A. \& REAL, R. 2008. AUC: a misleading measure of the performance of predictive distribution models. Global Ecology and Biogeography. 32: 1-5.

LOBO, J.M. 2008. More complex distribution models or more representative data? Biodiversity Informatics. 5: 14-19.

MAIA, J.G.S., ANDRADE, E.H.A., COUTO, H.A.R., SILVA, A.C.M.D., MARX, F. \& HENKE, C. 2007. Plant sources of Amazon rosewood oil. Química Nova. 30: 1906-1910.

MAIA, J.G.S. \& ANDRADE, E.H.A. 2009. Database of the Amazon aromatic plants and their essential oils. Quimica Nova. 32: 595-622.

MARCO JUNIOR, P. \& SIQUEIRA, M.F. 2009. Como determinar a distribution potencial de espécies sob uma abordagem conservacionista? Megadiversidade. 5: 65-76.

MILLER, J.S. \& MORGAN, H.A.P. 2011. Assessing the effectiveness of Madagascar's changing protected areas system: a case study of threatened Boraginales. Oryx. 45: 201-209.

MUÑOZ, M.E.S., DE GIOVANNI, R., SIQUEIRA, M.F., SUTTON, T., BREWER, P., PEREIRA, R.S., CANHOS, D.A.L. \& CANHOS, V.P. 2011. openModeller: a generic approach to species' potential distribution modelling. GeoInformatica. 15: 111-135.

MURRAY-SMITH, C., BRUMMITT, N.A., OLIVEIRA-FILHO, A.T., BACHMAN, S., MOAT, J., LUGHADHA, E.M.N. \& LUCAS, E.J. (2009) Plant Diversity Hotspots in the Atlantic Coastal Forests of Brazil. Conservation Biology. 23: 151-163.

NELSON, B.W., FERREIRA, C.A., SILVA, M.F.D. \& KAWASAKI, M.L. (1990) Endemism centres, refugia and botanical collection density in Brazilian Amazonia. Nature. 345(6277): 714-716.

NUNES, G.B.L., COSTA, L.M., GUTIERREZ, S.J.C., NUNES, L.C.C., \& DE FREITAS, R.M. 2014. Prospecção científica e tecnológica da Aniba riparia (Nees) Mez (Lauraceae). Cadernos de Prospecção. 6: 447-458.

PEARSON, R.G., RAXWORTHY, C.J., NAKAMURA, M. \& PETERSON, A.T. 2007. Predicting species' distributions from small numbers of occurrence records: a test case using cryptic geckos in Madagascar. Journal of Biogeography. 34: 102-117.

PEARSON, R.G. (2007) Species Distribution Modeling for Conservation Educators and Practitioners. American Museum of Natural History, New York.

PETERSON, A.T., PAPES, M. \& SOBERÓN, J. 2008. Rethinking receiver operating characteristic analysis applications in ecological niche modeling. Ecological Modelling 213: 63-72.

PETERSON, A.T., \& SOBERÓN, J. (2012) Species distribution modeling and ecological niche modeling: getting the concepts right. Natureza \& Conservação. 10: 102-107.

PHILLIPS, S.J., ANDERSON, R.P. \& SCHAPIRE, R.E. (2006) Maximum entropy modeling of species geographic distributions. Ecological Modelling. 190: 231-259.

PIO-CORRÊA, M. 1926-1978. Diccionário das plantas úteis do Brasil e das exóticas cultivadas. Vol I-IV. Imprensa Nacional, Rio de Janeiro. 
PROCÓPIO, L.C. \& SECCO, R.D.S. 2008. The importance of botanical identification in forest inventories: the example of "tauari"- Couratari spp. and Cariniana spp., Lecythidaceae - in two timber areas of the State of Pará. Acta Amazonica. 38: 31-44.

QUINET, A. 2005. Sinopse taxonômica da família Lauraceae no estado do Rio de Janeiro, Brasil. Acta Botanica Brasilica. 19: 563-572.

QUINET, A. 2006. Lauraceae na Reserva Biológica de Poço das Antas, Silva Jardim, Rio de Janeiro, Brasil. Rodriguésia. 57: 543-568.

QUINET, A., BAITELLO, J.B., MORAES, P.L.R., ASSIS, L. \& ALVES, F.M. (2015) Lauraceae. In: Lista de Espécies da Flora do Brasil. Jardim Botânico do Rio de Janeiro, Rio de Janeiro. Available from: http://www.floradobrasil. jbrj.gov.br/jabot/floradobrasil/FB143 (accessed: 09 May 2015).

RABINOWITZ, D., CAIRNS, S. \& DILLON, T. 1986. Seven forms of rarity and their frequency in the flora of the British Isles. In: M.E. Soule' (Ed.) Conservation biology. The science of scarcity and diversity. Sinauer Associates, Sunderland, pp. 82-204.

RUPPRECHT, F., OLDELAND, J. \& FINCKH, M. 2011. Modelling potential distribution of the threatened tree species Juniperus oxycedrus: how to evaluate the predictions of different modelling approaches? Journal of Vegetation Science. 22: 647-659.

SCHÖLKOPF, B., PLATT, J., SHAWE-TAYLOR, J., SMOLA, A.J. \& WILLIAMSON, R.C. 2001. Estimating the support of a high-dimensional distribution. Neural Computation. 13: 1443-1471.

SCHULMAN, L., TOIVONEN, T. \& RUOKOLAINEN, K. 2007. Analyzing botanical collecting effort in Amazonia and correcting for it in species range estimation. Journal of Biogeography. 34: 1388-1399.
SERRATO, A., IBARRA-MANRÍQUEZ, G. \& OYAMA, K. 2004. Biogeography and conservation of the genus Ficus (Moraceae) in Mexico. Journal of Biogeography. 31: 475-485.

SIMIĆ, A., SOKOVIĆ, M.D., RISTIĆ, M., GRUJIĆ-JOVANOVIĆ, S., VUKOJEVIĆ, J. \& MARIN, P.D. 2004. The chemical composition of some Lauraceae essential oils and their antifungal activities. Phytotherapy Research. 18: 713-717.

SIQUEIRA, M.F. \& DURIGAN, G. 2007. Modelagem da distribuição geográfica de espécies lenhosas de cerrado no Estado de São Paulo. Revista Brasil. Bot. 30: 233-243.

SIQUEIRA, M.F., DURIGAN, G., DE MARCO JÚNIOR, P., \& PETERSON, A.T. 2009. Something from nothing: using landscape similarity and ecological niche modeling to find rare plant species. Journal for Nature Conservation. 17: 25-32

SOBERÓN, J. \& PETERSON, A.T. 2005. Interpretation of models of fundamental ecological niches and species' distributional areas. Biodiversity Informatics, 2:1-10.

STOCKWELL, D.R.B. \& PETERSON, A.T. 2002. Effects of sample size on accuracy of species distribution models. Ecological Modelling. 148: 1-13.

SWETS, K. 1988. Measuring the accuracy of diagnostic systems. Science. 240: $1285-1293$.

YANGA, X.Q., KUSHWAHAB, S.P.S., SARANB, S., XUC, J. \& ROYB, P.S. 2013. MaxEnt modeling for predicting the potential distribution of medicinal plant, Justicia adhatoda L. in Lesser Himalayan foothills. Ecological Engineering. 51: 83-87. 